\title{
SLOVENSKO HRVAŠKA OBMEJNA REGIJA IN NJENE FUNKCIJE V POVEZOVANJU MED HRVAŠKO IN SLOVENIJO IN V LUČI EVROPSKE INTEGRACIJE
}

\author{
dr. Vladimir Klemenčič*
}

\section{Izvleček}

Avtor na primeru slovensko-hrvaške meje predstavi probleme na mikro- (lokalni) in makro-regionalni (meddržavni in evropski) ravni, ki so se pojavili ob vzpostavitvi slovensko-hrvaške meje po letu 1991. Na lokalni ravni predstavi negativne učinke meje $\vee$ življenju tamkajšnjega prebivalstva, na makro-regionalni ravni pa opredeli pomen tega prostora $v$ mednarodnem prometu.

Ključne besede: slovensko-hrvaška meja, obmejna regija, negativni učinki državne meje, prometna infrastruktura

\section{SLOVENE-CROATIAN BORDER REGION AND ITS FUNCTIONS IN RELATIONS BETWEEN SLOVENIA AND CROATIA AND IN LIGHT OF EUROPEAN UNION}

\begin{abstract}
The author treats borders and border regions between Slovenia and Croatia in the context of broader connections between two neighboring states and concepts of broader connections among the European states. The author deals with many problems on the local and macro-regional (European) level that came about when the Slovene-Croatian state frontier was established after 1991. This border is something special in Central Europe because it was established during a period when borders between countries of the EU are more or less nonexistent, while the number of border crossings at the borders of Eastern European countries is increasing.
\end{abstract}

Key words: Slovene-Croatian border, border region, negative consequences of the international border, traffic infrastructure

* Dr., red. prof., Oddelek za geografiio, Filozofska fakulteta, Aškerčeva 2, 1000 Ljubljana, Slovenija 


\section{Uvod}

Z osamosvojitvijo nekdanjih jugoslovanskih republik Slovenije in Hrvaške leta 1991 so se na obmejnih območjih ob novo nastali slovensko-hrvaški meji odprli mnogi problemi. Nova meja je - tako na slovenski kot na hrvaški strani - bistveno posegla $\vee$ življenje tamkajšnjega obmejnega prebivalstva, nekateri njeni učinki pa so zaznavni tako $v$ vsem slovenskem in hrvaškem prostoru kot tudi v širšem (zlasti srednjeevropskem) prostoru. Problemi so toliko boli pereči, ker se je slovensko-hrvaška meja izoblikovala $\vee$ glavnem na nerazvitih in perifernih območjih, ki so kazala znake demografske ogroženosti že v preteklih desetletiih, ko je imela ta meja le upravno-administrativni značaj, in ni predstavljala nobenih ovir za pretok osebnega in blagovnega prometa ter informacii (Klemenčič, 1993).

S problemi slovensko-hrvaške meje in tamkajšnjih obmejnih območij se je doslej ukvarjalo že precej raziskovalcev. Čeprav se je o tem že veliko govorilo in je tudi že precej napisanega, pa študije avtorjev različnih znanstvenih disciplin obravnavajo $v$ glavnem le parcialne probleme (Bufon, 1992). Zato se bo $\vee$ kratkem potrebno na interdisciplinarni osnovi lotiti raziskav funkcije slovensko-hrvaške meje in to tako glede na geopolitični položaj Slovenije, kakor tudi glede na položaj Slovenije kot obmejne regije $v$ procesih povezovanja z državami Evropske unije in povezovanja Slovenije in Hrvaške v tako imenovano "Evropo regii".

Dosedanje študije o problemih slovensko-hrvaške meje so se le redko ukvarjale z vprašanji povezanosti oziroma nepovezanosti obmejnih območij na obeh straneh meje. V glavnem obravnavajo številne probleme, s katerimi se srečuje obmejno prebivalstvo zaradi nekaterih nerešenih vprašani med Slovenijo in Hrvaško (zlasti dejstvo, da mejna črła - kljub prizadevanjem različnih mešanih komisii - na nekaterih območjih še danes ni natančno opredeljena).

\section{Učinki nove slovensko-hrvaške meje na lokalni ravni}

Kljub temu, da sta Slovenija in Hrvaška že leta 1991 ob svoji meji odprli 26 cestnih mejnih prehodov različnih kategorij, pa so ti - vsaj do neke mere zadostili le potrebam mednarodnega in meddržavnega prometa, na lokalnem nivoju pa je novo nastala meja povzročila obmejnemu prebivalstvu precej 
nevšečnosti (Klemenčič, Genorio, 1993). Čeprav sta obe državi ravno zaradi omenjenih težav $v$ naslednjih letih odprli več obmejnih prehodov, ki naj bi omilili težave obmejnega prebivalstva, pa se je položaj le malo izbolišal. Seveda tako stanje ne preseneča, če vemo da živi v občinah ob slovenskohrvaški meji na slovenski strani okrog 320.000 ljudi (od tega okrog 16.300 Hrvatov), na hrvaški strani pa okrog 1,6 milijona ljudi (od tega okrog 14.500 Slovencev - karta)

Negativni učinki nove slovensko-hrvaške meje prihajajo na lokalnem nivoju še toliko bolj do izraza zaradi dejstva, da vse od konca prve svetovne vojne pa do osamosvojitve Slovenije in Hrvaške (z izjemo časa med drugo svetovno vojno) na tem območju ni bilo nobene "pregrade", ki bi ovirala kakršnekoli oblike povezovanja tamkajšnjega prebivalstva. Tako je prihajalo do sklepanja številnih mešanih zakonskih zvez hrvaškega in slovenskega prebivalstva iz obmejnih naselij, ki so le utrievale povezovanje prebivalstva z obeh strani meje. $S$ porokami in $v$ povezavi $s$ tem tudi $z$ dedovanjem so prehajale nekatere parcele različnih zemliǰskih kategorij na hrvaški strani $v$ last slovenskega prebivalstva in obratno na slovenski strani $v$ last hrvaškega prebivalstva (Belec, 1992). Z vzpostavitvijo državne meje med Slovenijo in Hrvaško je taka lastniška struktura dobila dvolastniški značaj, pojavili pa so se tudi mnogi problemi, povezani z izrabo zemlje, sai je mejo mogoče prečkati le na točno določenih mestih (mejnih prehodih), ne pa tudi po številnih lokalnih poteh, ki povezujejo ta kmetijska zemliišča. Tako se je dostop do kmetijskih površin precej podaljšal, kar ob naraščanju cen pogonskih goriv na svetovnem trgu, le še otežuje položaj obmejnega kmečkega prebivalstva. Poleg oteženega dostopa do kmetijskih površin in $v$ zvezi $s$ tem povišanja izdatkov kmetijske pridelave, so se pojavili tudi problemi s plačevanjem davkov (katastrski dohodek), kar vse skupaj vpliva na izrabo zemlje na obeh straneh slovenskohrvaške meje. Zato ne preseneča dejstvo, da je na obmejnih (zlasti vinorodnih območjih) pogosto prihajalo do preprodaje zemlje, ki je stopnjevala razdrobljenost zemljiške in lastniške strukture (Belec 1992 in 1993). Kljub temu, da so omenjene probleme na nekaterih območjih skušali rešiti z medobčinskimi dogovori na lokalni ravni, pa težave niso odpravljene in bodo oteževale živlienje obmejnemu prebivalstvu vse, dokler Slovenija in Hrvaška ne bosta sprejeli ustreznega zakona ( $v$ prvi vrsti zakon o maloobmejnem prometu). 


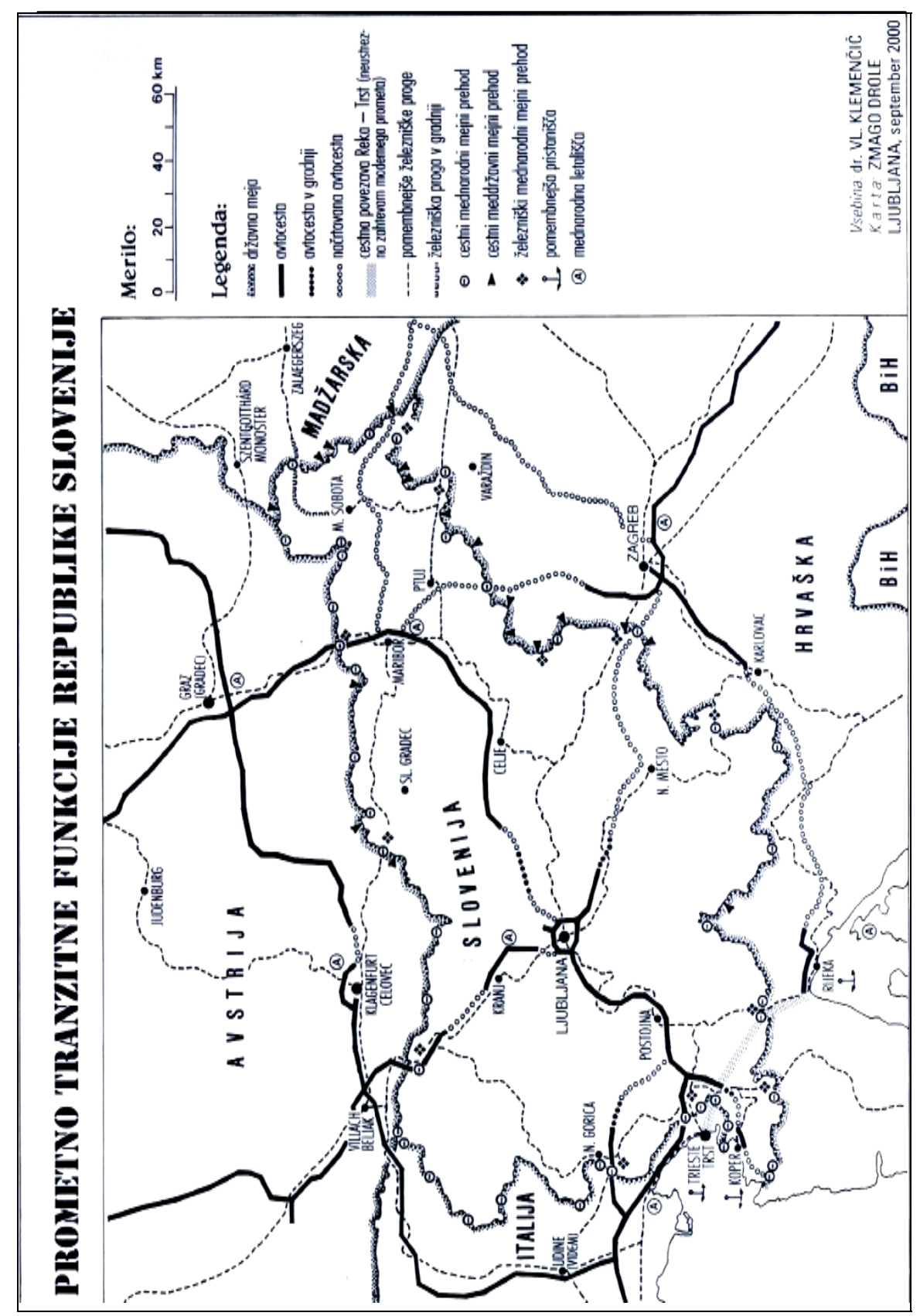


Negativni učinki meje so posegli tudi na področje uslužne obrti in trgovine, katerih se je prebivalstvo hrvaške strani posluževalo na slovenski, slovensko prebivalstvo pa na hrvaški strani meje. Do nekaterih omejitev je prišlo tudi na področju šolstva, saj so pred uveljavitvijo slovensko-hrvaške meje dijaki lahko obiskovali najbližjo šolo in to ne glede ali je bila na slovenski ali hrvaški strani. Ta pojar je bil bolj razširien pri srednješolskem izobraževanju, medtem ko je bil v osnovnošolskem (zaradi jasno opredeljenih šolskih okolišev) boli izjema. Pri tem pa moramo posebej poudariti, da jezik pri tem ni predstavljal posebne ovira, saj je bilo $v$ dialektih obmejnih krajev $z$ obeh strani meje veliko podobnosti.

Podobne težave kot na področju šolstva so se pojavile tudi na verskem področju, sai se obmejno prebivalstvo pri opravljanju verskih dolžnosti velikokrat ni oziralo, ali je bila najbližja cerkev na slovenski ali hrvaški strani. Po vzpostavitvi meje pa je bilo primorano - zlasti na območjih z redkimi mejnimi prehodi - opraviti to dolžnost $v$ najbližji cerkvi v domovini.

Nova slovensko-hrvaška meja, ki je marsikje presekala mikro-gravitacijska območja posameznih centrov zaposlitve, je obmejnemu prebivalstvu povzročila poleg oteženega prehajanja meje tudi težave pri zaposlovanju $z$ ene na drugo stran meje. Pri tem je potrebno omeniti, da je pred osamosvojitvijo Slovenije in Hrvaške ob tedanji administrativni meji potekala živahna izmenjava delovne sile med obmejnimi kraji zaposlitve, čeprav je šlo večinoma za periferna in manj razvita območja z nadpovprečnim deležem kmečkega prebivalstva, neurejeno infrastrukturo ter $\mathrm{z}$ visokim deležem nezaposlenih (Klemenčič, 1989). Ob naraščanju nezaposlenosti so se problemi odprli predvsem na obmejnih območjih na slovenski strani meje, kjer se je razvila le takšna industrija, za katero slovensko prebivalstvo ni imelo ustrezne strokovne izobrazbe. Zato, kljub večanju deleža nezaposlenih pri slovenskem prebivalstvu, zasedajo številna delovna mesta delavci iz Hrvaške, ki imajo za taka dela ustrezno kvalifikacijo. Čeprav sta obe državi z različnimi zakoni skušali zaščititi domače delavce, pa je zlasti Slovenija morala zaradi omenjenih razlogov vsaj v nekaterih primerih svojo zakonodajo omiliti. Tako je na primer morala Nafta Lendava za nemoteno proizvodno $v$ rafineriij zadržati del specializirane delovne sile iz Hrvaške, podobno pa je tudi steklarna Rogaška Slatina morala zadržati pihalce stekla, ki so v glavnem iz okoliških hrvaških naselii (Klemenčič, 1994). Podrobne raziskave te problematike bi pokazale, da je dnevna čezmejna menjava delovne sile, kljub veliki nezaposle-nosti zaradi 
nazadovanja števila delovnih mest $v$ industriii, vzdolž vse slovensko-hrvaške meje še vedno prisotna.

\section{Učinki slovensko-hrvaške meje na makroregionalni ravni}

Z novo mejo so se pojavili nekateri problemi tudi na makro-regionalni ravni. Tako je otežena nekdaj živahna gospodarska menjava med severovzhodno Slovenijo (zlasti Mariborom) na slovenski ter Medžimurjem in zahodno Podravino na hrvaški strani, zmanjšalo pa se je tudi živahno sodelovanje na področju višjega in visokošolskega izobraževanja. V Ljubljani je študiralo precej študentov iz Istre, $\vee$ Mariboru iz Medžimuria ter zahodne Podravine, v Zagrebu pa iz spodnjega Posavja ter Posotelja. Zaprtost meje je prizadela tudi izmenjavo na kulturnem področju, še posebno v sami obmejni regiji na obeh straneh meje (Klemenčič, Gosar, 1994).

Vsi zgoraj navedeni problemi, ki so nastali z uveljavitvijo slovensko-hrvaške meje in jih bo potrebno še rešiti, pa so ob italijansko-slovenski ter slovenskoavstrijski meji $v$ veliki meri že odpravljeni. Seveda je to samo po sebi razumljivo, saj so se ti problemi s ševilnimi mednarodnimi sporazumi odpravljali postopno skozi vseh štirideset let po "odprtju" omenjenih meja (Klemenčič, 1994). Reševanje problemov, ki so povezani z nastankom slovensko-hrvaške meje, pa bo moralo potekati na povsem spremenjenih izhodiščih, saj z nastankom te meje vsa Slovenija postopoma pridobiva funkcijo enotne obmejne regije.

Medtem, ko lahko na obmejnih območjih ob mejah Slovenije z Italijo, Avstrijo ter Madžarsko $v$ regionalni strukturi ugotavljamo funkcijo in učinke meje $\checkmark$ obsežnih ter diferenciranih prostorskih procesih in prostorskih strukturah, pa lahko ob novo nastali slovensko-hrvaški meji zasledimo znake obmejne regije le neposredno z mejnimi prehodi in infrastrukturo, potrebno za opravljanje mejnih formalnosti. Tudi o kakšni konkretnejši čezmejni povezanosti obmejnih območij z obeh strani slovensko-hrvaške meje skoraj ne moremo govoriti, saj je marsikje obmejnemu prebivalstvu otežena že osnovna čezmejna komunikacija. Tudi redki mejni prehodi in njihova neustrezna infrastrukturna opremljenost pomenijo veliko oviro blagovnemu in osebnemu prometu in to tako na lokalni, kakor tudi na meddržavni in mednarodni ravni. Ta problem je zlasti pereč na območjih, ki jih prečkajo prometne osi, ki so pomembne za vso Evropo, kot na primer mejna prehoda Obrežje in 
Bregana, preko katerih poteka pomembna evropska prometna transverzala, ki povezuje najrazvitejše dele severne in srednje Evrope z jugovzhodno Evropo in Bližnjim vzhodom (Klemenčič, Genorio, 1993).

Ko govorimo o neustrezni prometni infrastrukturi na slovensko-hrvaški meji, velja omeniti, da bo potrebno v najkrajšem času modernizirati in usposobiti za nemoten pretok osebnega in blagovnega prometa še mejne prehode na drugih mednarodno pomembnih prometnih smereh - na primer mejni prehod Gruškovje na "Phyrinski" cesti, ki povezuje del srednje Evrope (München, Dunai) s turistično Dalmacijo, ali pa mejna prehoda Rupa in Starod v smeri med Reko in Trstom. To bo še posebei pomembno z vključitvijo Hrvaške in Slovenije $v$ Evropsko unijo, ko bo (po predvidevaniih) prišlo do specializacije severno-jadranskih pristanišč (Reka, Koper, Trst), kar bo zahtevalo tudi prilagoditev prometne infrastrukture za nemoteno povezavo $s$ kontinentalno Evropo.

Seveda se Republika Slovenija zavzema za čim boli odprto slovenskohrvaško mejo tudi zaradi mednarodnega turističnega prometa, ki se iz evropskih držav preko Slovenije usmerja v turistično Istro in Dalmacijo, pa tudi ( $v$ bodočnosti verjetno še boli) $v$ države jugovzhodne Evrope in na Bližnji vzhod. Ovire pri tem se zaenkrat pojavljajo zlasti na smereh proti Istri in Kvarnerju; nekaj zaradi neustrezne infrastrukturne opremljenosti mejnih prehodov, nekaj pa zaradi nedograjenega slovenskega cestnega križa in slabše propustnosti cest $v$ sosednii Hrvaški. Vse te ovire pa - zlasti v poletnem času in ob koncu praznikov - ovirajo tudi tokovi osebnega prometa zdomcev iz Slovenije, Hrvaške in Bosne.

Prav gotovo vsi našteti problemi ožjega obmejnega prostora ob slovenskohrvaški meji, ki zavirajo Slovenijo $v$ njenem oblikovanju $v$ tako imenovano obmejno "evroregijo" in zmanjšujejo njen prometno-križiščni pomen, ne bodo izostali vse do vključitve Slovenije in Hrvaške v Evropsko skupnost.

\section{Zaključek}

Čeprav je slovenska geografija učinke meje pri interpretaciji regionalnega razvoja prostorskih struktur zaznala že zelo zgodai (Klemenčič, 1993), pa se zastavlja vprašanje, na kakšen način se lotiti reševanja problemov, ki so nastali z nastankom slovensko-hrvaške meje. Modeli, ki so veljali za reševanje problemov ob slovensko-italijanski, slovensko-avstrijski pa tudi slovensko- 
madžarski meji, verjetno ne pridejo $v$ poštev, saj so pogoji sedaj povsem spremenjeni. Zavedati se namreč moramo, da se je z nastankom slovenskohrvaške meje celotna Slovenija spremenila $v$ obmejno regijo. Zato se bo potrebno kompleksnih vprašani soodvisnosti problemov zaprte, priprte ali odprte meje lotiti z povsem drugih izhodišč. Večino problemov bo potrebno na novo proučiti in na novo opredelili položaj in funkcije Slovenije v Evropi (zlasti funkcijo mednarodne tranzitne regije, ki jo je Slovenija opravljala že $v$ preteklih zgodovinskih razdobjih, vendar na nižji stopnji prometne tehnologije).

Seveda pa se moramo tudi zavedati, da se bo ob reševanju omenjenih problemov odprla tudi vrsta neznank, ki jih bo mogoče šele sprotno definirali. Uspešnost bo odvisna od cele vrste dejavnikov, še zlasti od poznavanja dejavnikov sedanjih tendenc prostorskega razvoja Slovenije. Tega pa moramo, če hočemo biti z Evropo enakopravni in v njej avtonomni, ustrezno prilagajati tako interesom Slovenije kot tudi interesom Evrope.

\section{Literatura in viri}

Belec B., 1992: Nekaj značilnosti zemljiškoposestne in zaposlitvene povezanosti med republikama Slovenijo in Hrvatsko $v$ obmejnih območjih severovzhodne Slovenije. Geographica Slovenica 23. Ljubliana, Inštitut za geografijo univerze, str. 363-373.

Belec B., 1993: Prekomejna zemljiškoposestna pomešanost in zaposlovanje primer obmejnih občin SV Slovenije in Hrvaško. Dela 10. Ljubljana, Filozofska fakulteta, Oddelek za geografiio, str. 73-84.

Klemenčič V., 1989: Ländliche Räume Jugoslawiens in Spannungsfeld zwischen Abwanderung und Verdichtungprozessen. Landesentwicklung und Umweltschutz im Donauraum. München, Südosteuropa aktuell, str. 46-58.

Bufon M. 1992: Geografija obmejnosti: da ali ne? Dela 10. Liubljana, Filozofska fakulteta, Oddelek za geografiio, str. 345-362.

Klemenčič V., 1993: Geopolitični položaj ter teoretski in metodološki poizkus opredelitve tipov obmejnih območij na primeru Slovenije. Dela 10. Ljubljana, Filozofska fakulteta, Oddelek za geografijo, str. 9-20. 
Klemenčič V., Genorio, R., 1993: The new state of Slovenia and its function within the frame of Europe. GeoJournal, vol. 30, no. 3. London, Dordrecht, Boston, Kluwer Academic Publishers, str. 323-333.

Klemenčič V., 1994: Prostorsko-strukturne spremembe Slovenije kot nove države. Znanstvena revija, leto 6, št. 1. Maribor, Pedagoška fakulteta, str. 67-84.

Klemenčič V., Gosar, A., 1994: Current problems of border regions along the Croato-Slovene frontier. Political Boundaries and Coexistence. Proceedings of the IGU-Symposium, Basle/Switzerland, 24-17 May 1994. Bern, str. 30-42.

\section{THE SLOVENE-CROATIAN BORDER REGION AND ITS FUNCTIONS IN RELATIONS BETWEEN SLOVENIA AND CROATIA AND IN LIGHT OF THE EUROPEAN UNION}

\section{Summary}

The author treats borders and border regions between Slovenia and Croatia in the context of broader connections between two neighboring states and concepts of broader connections among the European states. The author deals with many problems on the local and macro-regional (European) level that came about when the Slovene-Croatian state frontier was established after 1991. This border is something special in Central Europe because it was established during a period when borders between countries of the EU are more or less nonexistent, while the number of border crossings at the borders of Eastern European countries is increasing.

During a period of opening of European borders, the problems that appeared at the Slovene-Croatian border represent a rare special problem, disrupting mutual relations established before 1991 in the economy, culture and education and making the lives of the inhabitants worse on both sides of the border. The farmers who own land on both sides of the border are in the worst situation.

Among the negative effects of the (newly established) Slovene-Croatian border, the author treats the problems of transfrontier employment, due not only to the establishment of the new national frontier but also to the lagging 
behind in economic development of the border regions. People are emigrating in large numbers from these regions. The author also discusses some other problems that could be extinguished with bilateral agreements between Slovenia and Croatia so as to reestablish the old connections among the people on both sides of the border.

The author gives special emphasis to the role and problems of the region alongside the Slovene-Croatian border at the macro regional level. The author also illuminates the problem and importance of the land connections of Croatia with Western and Southeastern and Eastern Europe through Slovenia and the importance of planning the future activities of the ports of Koper/=Capodistria, Trieste/=Trst and Rijeka.

At the end of the article the author offers some solutions to the problems that arose after the Slovenian-Croatian border was established as a national frontier. He concludes that the models introduced for solutions of similar problems at Slovene-Italian and Slovene-Austrian borders would not be useful under the changed circumstances, when Slovenia is in the process of European integration and is becoming a frontier region of Europe. 